\title{
Keys for peace in the Middle East: interview with Ambassador Itamar Rabinovich
}

Raphael Cohen-Almagor

Introduction

The United States is a powerful player with leverage and ability to drive the process forward; but successful mediation also requires impartiality and credibility. In 1974, Secretary of State Henry Kissinger was able to succeed in his mediation between Israel and Egypt because he was perceived as an objective, fair broker between the two sides. Kissinger was able to maintain a balanced view regarding the competing interests of Israel and Egypt. The same can be said about President Jimmy Carter1

1. In August 1978, President Jimmy Carter invited Prime Minister Menachem Begin and President Anwar Sadat to Camp David to negotiate a comprehensive Arab-Israeli peace. The summit began on September 5 and lasted 13 days, during which the Americans successfully mediated a peace agreement. On 17 September 1978, Sadat, Begin, and Carter signed the Camp David Peace Accords in Washington, D.C. See Carter, Keeping Faith: Memoirs of a President.

and his successful mediation in Camp David 1978.2

2. Bercovitch, ed., Resolving International Conflicts; Eizenstat, President Carter: The White House Years. Interview with President (ret.) Professor Aharon Barak, former legal advisor to PM Begin at Camp David 1978 (Herzliya, July 8, 2018).

But no such perception of the American broker was apparent in the peace summit of Camp David 2000. Arafat3

3. Mohammed Yasser Abdel Rahman Abdel Raouf Arafat al-Qudwa al-Husseini, known as Yasser Arafat, was Chairman of the Palestine Liberation Organization from 1969 to 2004 and President of the Palestinian National Authority from 1994 to 2004.

thought the American negotiating team had coordinated the negotiation plans with the Israelis. His suspicions were confirmed by American negotiators Kurtzer4

4. In his 29-year career in the U.S. Foreign Service, Daniel Kurtzer served as ambassador to Israel (2001-2005) and to Egypt (1997-2001). See Kurtzer et al., The Peace Puzzle.

and Miller. Aaron David Miller5

5. An American diplomat; expert on the Israeli-Palestinian conflict and U.S. policy in the Middle East. Miller is a former adviser to six secretaries of state (George Schultz to Colin Powell), and he helped shape America's policy in the region for more than two decades. See Miller, The Much Too Promised Land.

confessed: 'Not only did we consistently coordinate our positions with the Israelis, showing them our negotiating texts first - a practice I might add the Palestinians had come to expect - but we saw the issuess largely from Israel's point of view. I remember how impressed we all were when we learned that Barak was willing to concede 80 percent of the West Bank.' 6

6. Miller, "How Not to Host a Summit." See also Thrall, "Israel \& the US: The Delusions of Our Diplomacy." 
This is an Accepted Manuscript of an article published by Taylor \& Francis in Israel Affairs on 20 Jun 2019, available online: http://www.tandfonline.com/ 10.1080/13537121.2019.1626092.

The inability of the Palestinian negotiators to trust President Clinton7

7. William Jefferson Clinton served as the 42nd president of the United States from 1993 to 2001. See his book My Life.

undermined his position and his ability to relay information effectively to both sides. Presently the Palestinians have little reason to perceive President Trump8

8. Donald John Trump is the 45th and current President of the United States; he took office on 20 January 2017.

as an unbiased mediator. Thus they are trying to involve Europe in the process.

As the Americans continue to fail in their mediation attempts. Still senior Israeli and American diplomats continue to think that the role of the United States is irreplaceable. What can the USA do to be perceived as impartial in its mediation? What were the mistakes in Camp David? How could it be done differently? What lessons did the Americans learn? Is there a role for other countries to play in mediation? These and other questions are at a center of research that I have been conducting during the past decade. The research is based on primary sources: research in archives, and interviews with senior negotiators, politicians and implementers who were and are involved in peace negotiations.

This paper records one of the 35 interviews that I conducted until now with a seasoned scholar and diplomat: Professor Itamar Rabinovich. Rabinovich is the author of numerous books and articles about Israel and the Middle East.9

9. Books include: Syria under the Ba'th: 1963-1966: Army-Party Symbiosis; The War for Lebanon, 1970-1985; The Road Not Taken: Early Arab-Israeli Negotiations; The Brink of Peace: The IsraeliSyrian Negotiations; The Lingering Conflict; The View from Damascus; Receding Horizon; Yitzhak Rabin: Soldier, Leader, Statesman.

Between 1992 and 1996, he served as Israel's ambassador to the United States, and as Prime Minister Rabin's chief negotiator with Syria. Rabinovich has also wealth of experience in academic administration as he served Tel Aviv University in various capacities: Chairman of the Department of Middle Eastern Studies, Director of the Dayan Center for Middle Eastern and African Studies, Dean of Humanities, Rector and President. Politics in academia is different, yet in many respects similar, to state politics. Diplomatic and negotiation skills are certainly essential. The interview was conducted on 21 July 2017 at Tel Aviv University.

Cohen-Almagor:

What do you think are the keys to successful negotiations? I'm talking about peace negotiations, of course.

Rabinovich:

Yes. One is the determination by both sides to come to an agreement. The second is a sense of urgency. Both sides need to balance what I call pain and reward. As they reflect on the situation, leaders assess the desirable outcomes. They normally would be motivated either by the price of continuing the status quo, or the rewards of changing the status quo. This is 'the balance of pain and reward'. The third is very important: the sense of time. Is time working for me or against me? The 
This is an Accepted Manuscript of an article published by Taylor \& Francis in Israel Affairs on 20 Jun 2019, available online: http://www.tandfonline.com/ 10.1080/13537121.2019.1626092.

parties need to feel that time is not on their side, and that they need to conclude a peace deal now, rather than wait.

Cohen-Almagor:

Ripeness. The time has to be ripe for both of them.10

10. Zartman, Ripe for Resolution.

Rabinovich:

Yes. Well, ripeness is the overall outcome of all these constraints. Then the conflict can be sorted out. In 1992, 1993, both Rabin11

11. Yitzhak Rabin, 1922-1995; prime minister 1974-1977, and 1992 until his assassination in 1995.

and Arafat, for different reasons, felt that time was not on their side. And the fourth key to successful negotiations is that the regional-international environment is supportive. In Camp David 2000,12

12. The Camp David peace summit between Israel and the PLO was convened by President Clinton 11-24 July, 2000, at the presidential retreat outside Washington, D.C. See Pressman, "Visions in Collision."

the regional environment was not conducive, from the Palestinian point of view. The regional, the Arab environment, was not supportive. The Palestinians did not have support for concessions on Jerusalem and other issues that were considered all-Arab, not just Palestinian. And fifth, very important, is the role of the United States. The United States, normally as the convener, overseer of the process, can play an effective role or a less than effective role. Carter at Camp David 1978 was very effective with his manipulative skills. Clinton, in Camp David 2000, was less effective. So, these, I think, are the five most important determinants.

Cohen-Almagor:

You mentioned Carter in '78. Why do you think Camp David in '78 was successful, while Camp David in 2000 was a failure? What are the main differences?

Rabinovich:

The Israeli-Egyptian conflict is between states. The Israeli-Palestinian conflict is between unequal sides, between a state and a nonstate. The Israeli-Egyptian conflict is essentially a territorial conflict over the Sinai. Sadat13

13. Muhammad Anwar el-Sadat was the third President of Egypt, serving from 15 October 1970, until his assassination on 6 October 1981. See Sadat, In Search of Identity.

made a historic decision as he wanted to disengage from the conflict. Begin14

14. Menachem Begin was prime minister of Israel from 1977 to 1983.

made a historic decision as he was willing to give up the Sinai in return for peace provided that the Egyptians look away the Palestinian issue. Both Sadat and Begin dominated their political systems.

And Carter was a very good facilitator, because of his stubbornness and his manipulative skills. As for Camp David 2000, Arafat's sense of urgency changed between '92 and 2000. Some of the considerations in '92, when he felt that time was operating against him or against the Palestinian 
This is an Accepted Manuscript of an article published by Taylor \& Francis in Israel Affairs on 20 Jun 2019, available online: http://www.tandfonline.com/ 10.1080/13537121.2019.1626092.

national interests had changed, and Arafat began to feel better about the state of things. He was not in a hurry to conclude. Arafat was actually unwilling to come to Camp David. He was pressured to come and, in a way, was looking for a way out. Ehud Barak15

15. Ehud Barak, prime minister of Israel, 1999-2001.

could not cope with Arafat's reluctance and ultimate unwillingness to make the deal. Barak started the negotiations with massive demands and then, in a short time span, modified them significantly. Barak created the sense with Arafat that he could be pushed further. Barak arrived at Camp David basically without a coalition, without a government. His political future depended on the outcome, and Arafat felt that he had a very comfortable position vis-à-vis Barak. And the U.S. was not an effective mediator. Clinton is too nice a man. He is not Carter. And the Arab environment was not very helpful.

Cohen-Almagor:

What about the compositions of the teams? When you look at the composition at Camp David of all the parties and compare them to -

Rabinovich:

Of course, in the original Camp David, the Israeli team included three very important persons: Justice Aharon Barak,16

16. Aharon Barak was Dean of the Faculty of Law, The Hebrew University prior to his appointment as Israel's Legal Advisor to the Government. Subsequently he served as justice on the Supreme Court. Barak presided over the Court between 1995 and 2006.

Moshe Dayan17

17. Lieutenant General Moshe Dayan was PM Begin's Minister of Foreign Affairs.

and Ezer Weizman.18

18. Weizman was commander of the Israeli Air Force before he entered politics. He was PM Begin's Minister of Defense. See his book The Battle for Peace.

Dayan and Weizman wanted the deal, and Barak was very creative in devising solutions. Barak is not a jurist in the strict sense of the term. He is a very wise man that Begin trusted, and he played a very important role in finding bridging positions.

Cohen-Almagor:

What about the Americans? Quandt,19

19. Dr. William Quandt served as a staff member on the American National Security Council (19721974, 1977-1979). Author of Peace Process.

Saunders?20

20. Harold Henry Saunders served as the United States Assistant Secretary of State for Intelligence and Research between 1975 and 1978, and United States Assistant Secretary of State for Near East Affairs between 1978 and 1981. 
This is an Accepted Manuscript of an article published by Taylor \& Francis in Israel Affairs on 20 Jun 2019, available online: http://www.tandfonline.com/ 10.1080/13537121.2019.1626092.

Rabinovich:

Yes, they were gifted, but I don't think they were more gifted than Ross, 21

21. Ambassador Dennis Ross served as special Middle East coordinator under President Clinton, and is author of The Missing Peace.

Indyk,22

22. Martin Indyk served as U.S. ambassador to Israel from 1995 to 1997 and again from 2000 to 2001. He also served as special assistant to President Bill Clinton and senior director for Near East and South Asian affairs at the National Security Council (1993-1995) and as assistant secretary of state for Near Eastern affairs in the U.S. Department of State (1997-2000). Indyk is the author of Innocent Abroad.

Kurtzer and Miller who served on the Clinton peace team. I don't see a difference there. The difference was in the persona of Carter himself.

Cohen-Almagor:

Did Ehud Barak met with Arafat?

Rabinovich:

For a long time, no. Barak's and Arafat's personalities did not match.

Cohen-Almagor:

Did Barak and Arafat ever meet at Camp David?

Rabinovich:

They met. Don't you remember the famous picture?

Cohen-Almagor:

Yes, but I mean a constructive meeting. I mean, did they meet for business?

Rabinovich:

You mean, did they have a meeting of the minds?

Cohen-Almagor:

Yes.

Rabinovich:

No. They wanted different things. As I said, Arafat was only looking for a way out and, finally, he found it over Jerusalem. Then he escaped.

Cohen-Almagor:

Is the United States' involvement crucial in this?

Rabinovich: 
This is an Accepted Manuscript of an article published by Taylor \& Francis in Israel Affairs on 20 Jun 2019, available online: http://www.tandfonline.com/ 10.1080/13537121.2019.1626092.

Yes.

Cohen-Almagor:

It is. Is it possible to solve the conflict without the United States?

Rabinovich:

It is very difficult. The question is, when, at what optimal point in time, should the United States step in? In my view, the United States needs to come in towards the end. When the parties have covered, let's say, $80-90 \%$ of the issues, when they need to finalize the details; then the United States can facilitate. It is easier for the parties to make concessions to the President of the United States than to each other. And the United States is the underwriter of the deal. The Egyptian-Israeli peace is actually a trilateral deal, also with the United States. Everybody wants also a deal with the United States. So, it is even preferable to begin without the United States, in secret negotiations, away from public scrutiny. At some point, when it is ripe, disclose the negotiaitons. And later on, at the very end of the negotiations, bring the United States in. It is wrong to have the United States early in the talks as a mediator. The two sides should negotiate directly first. Mediation should follow negotiation, not replace it.

Cohen-Almagor:

The formula you said sounds very much like the Oslo formula,23

23. The Oslo peace channel was established in 1993 by Yossi Beilin, Terje Rød-Larsen and Yair Hirschfeld who understood Yassir Arafat's need to initiate a new path for relationships with Israel. See Pruitt, "Ripeness Theory and the Oslo Talks."

which didn't prove itself very well.

Rabinovich:

Yes, that is true. I have in mind the Egyptian-Israeli peace process. The basic outline of the deal was drawn by Dayan and Tohami, in secret.24

24. On 16 September 1977, Foreign Minister Moshe Dayan flew secretly to Morocco and met with Egyptian deputy prime minister Hassan Tohami. See Aderet, "Behind the Scenes of Anwar Sadat's Historic Visit to Jerusalem"; and Zion, "Untold story of the Mideast talks."

When Sadat came to Jerusalem, the outline of the deal was already made. The United States came in later.

Cohen-Almagor:

So, you think Oslo was a success?

Rabinovich:

Oslo was a success in the sense that a deal was made. You can argue about the quality of the deal, but a deal was made.

Cohen-Almagor:

Okay, let's speak about the quality of the deal. Do you think it was enough to base on it peace between Israel and the Palestinians? 
This is an Accepted Manuscript of an article published by Taylor \& Francis in Israel Affairs on 20 Jun 2019, available online: http://www.tandfonline.com/ 10.1080/13537121.2019.1626092.

Rabinovich:

I think it provided a basis for making a deal. Remember, Oslo was an interim agreement. It was very much predicated on the autonomy plan. 25

25. Sicherman, Palestinian Autonomy, Self-Government and Peace.

And there were five years for turning it into a deal. Now, both sides sinned against it. Arafat did not really fight terrorism; he did not clamp down on Hamas. We, the Israelis, did not deal with the settlement issue. Settlement construction continued.

There is peacemaking and peace building. There was very little peace building done during that time. So, I think, there were some flaws in Oslo. If you read Joel Singer's testimonies, you see that he was brought in at a later stage of the negotiaitons and didn't like the document he saw. He thought the document prepared by Hirschfeld26

26. Dr. Hirschfeld is an Israeli academic who was Beilin's partner for negotiations with the Palestinians for a number of years. See Hirschfeld, Track-Two Diplomacy toward an IsraeliPalestinian Solution 1978-2014.

and Pundak27

27. Ron Pundak was an Israeli historian and journalist. See his book Secret Channel.

was amateurish.28

28. See Cohen-Almagor, "The Oslo Peace Process: Interview with Joel Singer."

He tried to fix it. He was told, actually, to start afresh and he was told that there was no time. So, basically, he fixed something that was flawed in many respects. So, there are problems with the agreement, but, still, if both sides were determined from that point on to use the five years to really move from interim stage to final status, and build the peace, then it could have been done.

Cohen-Almagor:

Singer is one of the people I interviewed. Is there any other mediator who can fill the role of the United States?

Rabinovich:

No. I mean there could be other mediators. For instance, when Olmert29

29. Ehud Olmert, Israeli prime minister, 2006-2009. See his book In First Person.

dealt with Bashar al-Assad,30

30. Bashar Hafez al-Assad has been the President of Syria since 17 July 2000.

the Turks were mediators. There was no direct contact between Olmert and the Syrians. His people came to Turkey. There was a Syrian delegation in Turkey, and the Turks shuttled between the two delegations. It was unsuccessful mediation. So, you know, there can be other mediators, but no one has the sum total of the advantages that the United States brings to the table.

Cohen-Almagor:

Europe? The Quartet? 
This is an Accepted Manuscript of an article published by Taylor \& Francis in Israel Affairs on 20 Jun 2019, available online: http://www.tandfonline.com/ 10.1080/13537121.2019.1626092.

Rabinovich:

No. The Israelis don't trust the Europeans. The Europeans cannot be the underwriter in case the agreement collapses. You don't see the European cavalry coming. Europe is always interested in making its way into the negotiation, but it needs to win the trust of the Israelis and apparently it doesn't have it.

Cohen-Almagor:

Russia?

Rabinovich:

Definitely not.

Cohen-Almagor:

China?

Rabinovich:

China is not really involved.

Cohen-Almagor:

I'm talking in the long-term.

Rabinovich:

Years from now, when China becomes diplomatically involved in the Middle East, maybe. But, at this point, it is not. Not relevant.

Cohen-Almagor:

Arab countries?

Rabinovich:

Arab countries can facilitate, not mediate. Egypt facilitates with the Palestinians. It is the only other Arab country that facilitates.

Cohen-Almagor:

Saudi Arabia?

Rabinovich:

Again, there is not enough of a relationship between Israel and Saudi Arabia for Israel to really trust the Saudis. It is a very superficial relationship at this point. And judging by their performance on foreign policy I'm not sure that they have the skills.

Cohen-Almagor:

The 2002 Arab Initiative?31

31. The Arab Peace Initiative, initiated by Saudi Arabia, a succinct 7-point proposal to end the ArabIsraeli conflict that was endorsed by the Arab League in 2002 at the Beirut Summit, 
This is an Accepted Manuscript of an article published by Taylor \& Francis in Israel Affairs on 20 Jun 2019, available online: http://www.tandfonline.com/ 10.1080/13537121.2019.1626092.

http://news.bbc.co.uk/1/hi/world/middle_east/1844214.stm. See also Friedman, "An Intriguing Signal From the Saudi Crown Prince."

Rabinovich:

That is not mediation. That is facilitation. You need the Arab countries to be there to support the Palestinians, to encourage them, to supplement the concessions that the Palestinians can make, the concessions they can make in order to enrich the deal. There is no sense of a zero-sum game between Israel and the Arab countries, so they can and need to play a very important role, but not as the mediators.

Cohen-Almagor:

What about small states, like Norway and Sweden?

Rabinovich:

Facilitators, as Norway was in Oslo.32

32. See Waage, Peacemaking is a Risky Business.

Cohen-Almagor:

Not more?

Rabinovich:

No. Right now, Israel does not trust Sweden. Israel views Sweden as a semi-hostile country.

Cohen-Almagor:

Okay. And, if you look at Oslo and Stockholm 2000,33

33. Another backchannel negotiating track was established between Shlomo Ben-Ami and Abu Ala, who were joined by Gilead Sher and Hassan Asfour. This track known as the 'Stockholm track' because negotiaitons too place in part in Harpsund, Sweden. The first round of talks took place from May 11 to 17 May 2000. The second round began on May 20 but was suspended because of violence that erupted in the West Bank and Gaza Strip. The third and final round was held in Israel in June of the same year. These talks led to Camp David. See Eriksson, Small-State Mediation in International Conflicts.

do you think they did more than facilitation, or it was pure facilitation?

Rabinovich:

No, pure facilitation.

Cohen-Almagor:

No mediation.

Rabinovich:

Unless you see the play in New York - Oslo.

Cohen-Almagor:

I've seen it already. 
This is an Accepted Manuscript of an article published by Taylor \& Francis in Israel Affairs on 20 Jun 2019, available online: http://www.tandfonline.com/ 10.1080/13537121.2019.1626092.

Rabinovich:

Yes. Bad play.

Cohen-Almagor:

Holst. Do you know anything about his involvement in this?34

34. Foreign Minister Johan Jorgen Holst of Norway (1993-1994) helped guide the secret talks between Israel and the PLO.

Rabinovich:

Holst. I met him when he came with Peres35

35. At that time, Shimon Peres was Minister of Foreign Affairs in the Rabin government.

to brief Warren Christopher36

36. Warren Christopher, U.S. secretary of state, 1993-1997.

on the deal in August 1993. I'm not really familiar with the role he played during those conversations.

Cohen-Almagor:

Okay. Let's move to present time, 2017, today. Do you think that Israel and the PLO can resolve the differences between them?

Rabinovich:

No.

Cohen-Almagor:

Why?

Rabinovich:

Well, at this point, Israel has a right-wing government. The most right-wing government we ever had, and the worst government we ever had. There are elements in the coalition that are absolutely opposed to a deal. The government includes people like Naftali Bennett who are to the right of Likud. They have a zero-sum game view of the Israeli-Palestinian relationship. 'If it is good for the Palestinians, it is bad for us.' Housing in Qalqilya? No way. An island off Gaza to solve some of the issues of Gaza? No way. So, definitely not the kind of concessions that would be required in order to make the final deal. Right now, we don't have a government that is either interested or capable. I think, essentially, it is also true for the Palestinian side. I don't think Abu Mazen37

37. Mahmoud Abbas, also known as Abu Mazen, is the President of the Palestinian Authority. He has been the Chairman of the Palestine Liberation Organization since 11 November 2004, and Palestinian president since 15 January 2005.

is capable of giving Israel what it ultimately wants, that is finality, end of conflict. He could have had in the past. I think he missed it, he missed it with Olmert, and also in the negotiations with Kerry.38

38. John Forbes Kerry served as the 68th United States Secretary of State from 2013 to 2017. 
This is an Accepted Manuscript of an article published by Taylor \& Francis in Israel Affairs on 20 Jun 2019, available online: http://www.tandfonline.com/ 10.1080/13537121.2019.1626092.

I'm not sure that Netanyahu39

39. Benjamin Netanyahu was Israel's prime minister during Kerry's attempts to neogiate between Israel and the PLO.

acted in good faith, but he responded to Obama40

40. Barack Hussein Obama served as the 44th president of the United States from 2009 to 2017.

and Abu Mazen did not respond. So, I think Abu Mazen would like to see a breakaway Palestinian statehood. Not an agreement that would require him to sign finality on the dotted line. I think the region is in a very bad shape. When, you know, Iran is on the charge; Russia is active in the region; the United States is led by a peculiar president like Trump, whom nobody knows, who you definitely cannot trust. It is not the environment for making a final deal. My recommendation would be to go for an interim agreement. It would stop the gliding towards one-statehood. Many elements could be fitted into such an interim deal. And let the situation rest for a few years.

Cohen-Almagor:

What does 'breakaway state' mean?

Rabinovich:

'Breakaway statehood' means that the international system would recognize the State of Palestine, without an agreement.

Cohen-Almagor:

Do you see it happening?

Rabinovich:

No, but this is what Abu Mazen wants.

Cohen-Almagor:

From what I hear from you, it seems that there is quite a similarity of interests between the right elements of the Israeli government and the Palestinians who are opposed to Abu Mazen.

Rabinovich:

Yes. You know, you always have to look at politics as a circle. And both ends of the cycle are actually quite close to one another. In a way, both the radical right-wing in Israel and many Palestinians want one state. They have different concepts or visions of that state, but they want one state.

Cohen-Almagor:

How do we deal with spoilers? How do we deal with Hamas? Is Hamas an Israeli problem, Palestinian problem, both? How do you address this thing?

Rabinovich:

Both.

Cohen-Almagor:

But who is to address it first and foremost? 
This is an Accepted Manuscript of an article published by Taylor \& Francis in Israel Affairs on 20 Jun 2019, available online: http://www.tandfonline.com/ 10.1080/13537121.2019.1626092.

Rabinovich:

Well, when conditions will be ripe for a deal, which at present they are not, then Israel, the Palestinian Authority, and the major Arab states need to put together a strategy for dealing with Hamas. I think some people on the Israeli right-wing would be happy with what I call a three-state solution. Different, separate entities in Gaza and in the West Bank. But, you can deal with Hamas only when both sides identify that they are willing to move towards a final agreement, and then they need, together, to formulate the strategy for dealing with Hamas.

Cohen-Almagor:

A violent strategy?

Rabinovich:

Possibly.

Cohen-Almagor:

Because in order to distinguish itself, that is what Hamas does. It creates violence.

Rabinovich:

For instance, if there is another round of fighting in Gaza and this time Israel walks in and destroys Hamas, Abu Mazen could then come in. But, at this point, he doesn't want to come in, on Israeli bayonets. But if there is a deal, if this leads immediately to serious negotiations, and a deal materializes at the end of the negotiations, and he comes in, not on Israeli bayonets, but to incorporate Gaza into the Palestinian state that he gets - that is a different situation.

Cohen-Almagor:

Okay. Do you think this government is able to do an interim agreement? Is it something that the Israel government would like, to have an interim agreement?

Rabinovich:

No.

Cohen-Almagor:

No. So, you are not very optimistic at this present time.

Rabinovich:

No. I think it needs to go.

Cohen-Almagor:

The government?

Rabinovich:

Yes.

Cohen-Almagor:

Will it? Can you see it going? 
This is an Accepted Manuscript of an article published by Taylor \& Francis in Israel Affairs on 20 Jun 2019, available online: http://www.tandfonline.com/ 10.1080/13537121.2019.1626092.

Rabinovich:

I can see it going. I'm not sure, but I can see a number of scenarios for this government going. But, you know, this government cannot agree on any positive steps regarding the Palestinians. You have a right-wing defense minister like Lieberman, putting together a very reasonable plan for building several thousand units in Qalqilya. He cannot get it through the cabinet.

Cohen-Almagor:

Gabbay41

41. Avi Gabbay became leader of the Israeli Labour Party in 2017.

can lead it forward? Be an opposition?

Rabinovich:

Not from the opposition.

Cohen-Almagor:

Can he offer an opposition to Bibi Netanyahu? Can he win elections?

Rabinovich:

Can he defeat him in elections? I think he could. He has a potential.

Cohen-Almagor:

The two-state solution. Is it still viable?

Rabinovich:

Still viable, yes.

Cohen-Almagor:

So, you're still hopeful about a two-state solution. Still on the table.

Rabinovich:

Hopeful, yes.

Cohen-Almagor:

Okay. Tell me about Syria. That is something close to your heart. How did it all start for you?

Rabinovich:

It started in July 1992, when Rabin invited me to his home.

Cohen-Almagor:

You were at that time - ?

Rabinovich:

I was the Provost of Tel Aviv University.

Cohen-Almagor: 
This is an Accepted Manuscript of an article published by Taylor \& Francis in Israel Affairs on 20 Jun 2019, available online: http://www.tandfonline.com/ 10.1080/13537121.2019.1626092.

Did you know him before?

Rabinovich:

Oh, yes, we knew each other. We had a professional relationship and a superficial social friendship. Rabin offered me the role of chief negotiator and alluded to the Washington embassy as well. As a second phase. So, I became the chief negotiator. I did that for a few months. By November' 93 , my relationship with Rabin became very close and then he told me that I will be the next Israeli ambassador to Washington, which materialized in February '93. At first, I used to shuttle two weeks in every month to take part in negotiations in Washington, and when I became the ambassador I resided in Washington. I did that until November '95, when Rabin was assassinated. When Peres became prime minister, he wanted me to remain as ambassador, but he gave the Syrian negotiations file to Uri Savir. I remained part of the team, and when Netanyahu was elected prime minister in 1996 I resigned

Cohen-Almagor:

Did Rabin trust the Syrians?

Rabinovich:

Trust whom?

Cohen-Almagor:

Assad. The father.

Rabinovich:

No. But Rabin had high regard for him. Rabin thought that Assad was very difficult to negotiate with, but if and when he will make a deal, Assad will keep it. Later, in 1995, Rabin came to the conclusion that Assad wasn't really interested in a deal. He told me that.

Cohen-Almagor:

Why is that? Why do you think so?

Rabinovich:

Because there were two important meetings between the chiefs of staff of the two armies. Ehud Barak with Hikmat Shehabi, and then Amnon Lipkin-Shahak42

42. Amnon Lipkin-Shahak was the IDF's 15th General Staff (1995-1998).

with Shehabi. The Shahak-Shehabi was a very good meeting actually, but then, when Shehabi returned to Syria and reported in person to Assad, Assad decreed that it was a bad meeting - which it was not. And Rabin told me that there would not be a deal with Assad in conventional negotiation. Rabin thought that a different approach was needed for dealing with Syria. A fresh tactic.

Cohen-Almagor:

Now, can you tell me what did Rabin was willing to do. What concessions did he propose?

Rabinovich:

Full withdrawal from the Golan Heights. 
This is an Accepted Manuscript of an article published by Taylor \& Francis in Israel Affairs on 20 Jun 2019, available online: http://www.tandfonline.com/ 10.1080/13537121.2019.1626092.

Cohen-Almagor:

Until where? What's the boundary?

Rabinovich:

The lines of 4 June 1967.

Cohen-Almagor:

Okay. So, Assad would be able to approach the Kinneret [Sea of Galilee]?

Rabinovich:

Yes.

Cohen-Almagor:

And put his legs in the waters of the Kinneret?

Rabinovich:

Well, you always had to demarcate. You know, the lines of 4 June 1967 -

Cohen-Almagor:

These lines are contested.

Rabinovich:

Yes, they are contested, so that could be negotiated. Assad wanted the principle; he wanted to get more than Sadat.

Cohen-Almagor:

He wanted access to the water.

Rabinovich:

Not neccessariily. It is not a question of access to the water. First of all, I'm not sure that he really wanted to make a deal, because, remember, this regime needed an enemy. If this regime was to make peace, then what would be the rationale of having this dictatorship? But, let's say that he was interested in a deal. Primarily in a deal with Washington, and peace with Israel is part of it. Let's say that he was interested. He would only do that if he would emerge triumphant from it. He didn't want to be seem as capitulating. Of course, if Assad emerges triumphant, what does Rabin look like? It was very difficult to balance that approach.

Cohen-Almagor:

But he was willing to withdraw. Rabin was willing to withdraw.

Rabinovich:

Yes, that was the basis of the breakthrough in negotiations,

Cohen-Almagor:

And this is what he offered them explicitly? 
This is an Accepted Manuscript of an article published by Taylor \& Francis in Israel Affairs on 20 Jun 2019, available online: http://www.tandfonline.com/ 10.1080/13537121.2019.1626092.

Rabinovich:

Not explicitly.

Cohen-Almagor:

Not explicitly.

Rabinovich:

He gave it as a hypothetical condition, a willingness to withdraw, to Christopher. As a deposit.

Cohen-Almagor:

Yes, that is the 'pocketed deposit'?

Rabinovich:

The 'pocketed deposit'.43

43. Rabin handed to Christopher and Ross the so-called 'deposit' or the 'pocket' on Golan. He gave to Christopher and Ross a diplomatic gift, that is, Israel would be ready to meet Assad's requirements on territory, if Assad would be ready to meet Israel's requirements on security and peace. See Cohen-Almagor, "The Israel-PLO Peace Talks."

Cohen-Almagor:

Okay. And then Christopher told this to Assad.

Rabinovich:

Yes, Christopher overtold it, and Christopher did not use the 'pocket' wisely.

Cohen-Almagor:

Yes. That I understand. So, why did Assad decline at the end, if he got what he wanted? Did he want anything else?

Rabinovich:

Yes, but, you know, the question is what are the terms of the peace treaty? What does normalization mean? What are the security arrangements? What is the time structure? Rabin wanted a lot of normalization up front, to build up support in the Israeli public before the first removal of a settlement. All of these elements were not necessarily acceptable to Assad. We spent a month arguing about the principle of equality in the security arrangements. In our view, if we were withdrawing from the high ground to the valley, then we needed to be compensated in the security arrangements. Assad's point of view was: you, Israel, do not make any concessions, because you're withdrawing from something that is not yours. And I am the victim, I'm not the offender. If anybody needs security arrangements, it is me, it is not you. It was very difficult to negotiate all these issues.

Cohen-Almagor:

I see. So, neither side received what it wanted. That was the issue. That brought about the failure.

Rabinovich:

Yes. 
This is an Accepted Manuscript of an article published by Taylor \& Francis in Israel Affairs on 20 Jun 2019, available online: http://www.tandfonline.com/ 10.1080/13537121.2019.1626092.

Cohen-Almagor:

Okay. Do you see any similarities and differences between negotiations with the PLO and with Syria? I mean, don't repeat what you said about Egypt, but are there any other similarities and differences?

Rabinovich:

Well, at that time, yes. You know, in Syria, basically, you dealt with one man who dominated the system. All the negotiators were reciting Assad. And Syria was a state. The PLO is not a state. It is a community, an organization, that was led by a very peculiar leader (Arafat). Somebody who did not act as a head of state, but more like the head of a national liberation organization. So, there's a big difference.

Cohen-Almagor:

Do you think that Arafat wanted peace at any point?

Rabinovich:

I think that in 1992 and 1993, when he felt weak and time was on the side of Israel, he wanted to settle. In 2000, he no longer wanted to settle.

Cohen-Almagor:

What about all the terrorist events that took place from 1991 to 2000? And then the Second Intifada, all these terrorist events. Do you think that they were -

Rabinovich:

As I said, he was not willing to crack down on Hamas.

Cohen-Almagor:

Do you think it was only Hamas?

Rabinovich:

Hamas or Islamic Jihad.

Cohen-Almagor:

But not one of the factions of the PLO.

Rabinovich:

That was not the issue. I had a conversation with a leading Palestinian intellectual who told me, 'We learned from your history. We also need to have an Altalena.' But there was no Altalena, because Arafat wanted Hamas for the confrontation that eventually happened in the Second Intifada. He was not willing to crack down on them. Second, there was the role of Iran and its direct relationship with Hamas, designed to obstruct the process.

Cohen-Almagor:

In 2000, do you think he was behind the Intifada?

Rabinovich:

Who? 
This is an Accepted Manuscript of an article published by Taylor \& Francis in Israel Affairs on 20 Jun 2019, available online: http://www.tandfonline.com/ 10.1080/13537121.2019.1626092.

Cohen-Almagor:

Arafat?

Rabinovich:

Not at the outset, but, soon thereafter, he took it over.

Cohen-Almagor:

So, the starting point was what?

Rabinovich:

Spontaneous.

Cohen-Almagor:

Like in ' 87 ?

Rabinovich:

Like the first, but, soon enough, Arafat turned it into a war of attrition.

Cohen-Almagor:

Months, or weeks, or what do you think?

Rabinovich:

I cannot give you the precise timeline, but he did not initiate it. Once it broke out, Arafat took charge and turned it into a war of attrition.

Cohen-Almagor:

What do you think Netanyahu wants? What is the endgame for Israel today?

Rabinovich:

I'm not sure that he really has an endgame. Netanyahu, basically, is a status quo man. He's not the man who is going to change the status quo.

Cohen-Almagor:

But he does. The settlements are growing.

Rabinovich:

Netanyahu is not a man of big moves. But you are right: In reality, there is no status quo. There is a drift towards one-statehood. You know, he's essentially a right-wing, traditional right-wing revisionist Israeli. It is not his instinct to be a peacemaker with the Palestinians. He oversees this process of gradual drift towards one-statehood.

Cohen-Almagor:

Does he want it?

Rabinovich: 
This is an Accepted Manuscript of an article published by Taylor \& Francis in Israel Affairs on 20 Jun 2019, available online: http://www.tandfonline.com/ 10.1080/13537121.2019.1626092.

I'm not sure that he would tell you that he consciously wants it, but, de facto, that is what is happening.

Cohen-Almagor:

Do you think that he wants to annex any of the territories?

Rabinovich:

No.

Cohen-Almagor:

Area C?

Rabinovich:

No, but he is under the pressure of Bennett, fighting over the right-wing vote, so he gets carried away.

Cohen-Almagor:

Do you think he's going to annex any part of the West Bank?

Rabinovich:

Probably not. No, the United States will not allow that, and he won't. I don't think that he will do that.

Cohen-Almagor:

So, he's just going to continue building within the settlements.

Rabinovich:

Right.

Cohen-Almagor:

Is that the endgame?

Rabinovich:

It is not an endgame. It is the conduct of somebody who drifts.

Cohen-Almagor:

So, there's no endgame for Israel.

Rabinovich:

No, for Netanyahu there is no endgame. He's not somebody who would make the historical decision that, de facto, would incorporate the West Bank into Israel. 'I get rid of as many Palestinians as I can', blah blah blah.

Cohen-Almagor:

He doesn't have that.

Rabinovich: 
This is an Accepted Manuscript of an article published by Taylor \& Francis in Israel Affairs on 20 Jun 2019, available online: http://www.tandfonline.com/ 10.1080/13537121.2019.1626092.

No. But I said, de facto, he is drifting towards the same thing.

Cohen-Almagor:

You mentioned that you still support the two-state solution.

Rabinovich:

Right.

Cohen-Almagor:

Okay. Are there any other possible visions for the future? If this is not going to happen.

Rabinovich:

If it is not going to happen, the result would be one-statehood.

Cohen-Almagor:

Apartheid. Are we going to give the Palestinians any rights? Citizenship?

Rabinovich:

Eventually, if this continues, there will be another intifada. It is not going to stay the same.

Cohen-Almagor:

There will be another intifada, and then we are going to crush them, and then what?

Rabinovich:

Then the Israeli public may oust the government, because of the cost of the intifada.

Cohen-Almagor:

Cycles. You think there's going to be another cycle of violence. So, you think there's going to be more bloodshed, but, in the end, something different is going to develop.

Rabinovich:

Right. Change in Israel may not happen before there is another crisis.

Cohen-Almagor:

Sad, isn't it? We touched upon Oslo. Do you have anything more that you want to say about Oslo? Did you have any discussions with Rabin about Oslo? Is there something that you discussed?

Rabinovich:

No, nothing. He always expressed his ambivalence about Oslo. It was not his first choice. His choice was the Syrian deal.

Cohen-Almagor:

Okay. So, we know that Oslo started behind his back.

Rabinovich: 
This is an Accepted Manuscript of an article published by Taylor \& Francis in Israel Affairs on 20 Jun 2019, available online: http://www.tandfonline.com/ 10.1080/13537121.2019.1626092.

Yes, but he accepted it and he actually was very much involved throughout the late winter and spring of '93. He was briefed, he made decisions. He oversaw the negotiations. While he was very much involved, he was also ambivalent.

Cohen-Almagor:

Tell me about this. What was the ambivalence? Why was he ambivalent?

Rabinovich:

Because he saw the flaws in Oslo. He never fully trusted Peres. He wasn't sure that he was hearing the full story. And he still thought that the better option for Israel is to build the peace process on the Syrian leg, not on the Palestinian leg.

Cohen-Almagor:

But once it was happening -

Rabinovich:

Once he realized that he had no Syrian option, he was determined to move on with the Palestinians. He felt that Israel must move on in the peace process. That was the fundamental decision he made. Since he could not move on on the Syrian front, he authorized the signing of Oslo.

Cohen-Almagor:

Was there any trust between him and Arafat?

Rabinovich:

At that point, definitely not. Later on, there was no trust, but they learned to work together.

Cohen-Almagor:

In '94, '95, until his death.

Rabinovich:

Yes.

Cohen-Almagor:

And they had a good working relationship between them?

Rabinovich:

I wouldn't call it good. Functioning.

Cohen-Almagor:

Functioning. Okay. And any views about Stockholm? Do you know anything about the process in Stockholm?

Rabinovich:

I don't know much about Stockholm.

Cohen-Almagor: 
This is an Accepted Manuscript of an article published by Taylor \& Francis in Israel Affairs on 20 Jun 2019, available online: http://www.tandfonline.com/ 10.1080/13537121.2019.1626092.

Okay. Looking at the second Camp David, is there anything that you'd do differently?

Rabinovich:

You know, I would have invested more in the personal relationship with Arafat, because, ultimately, on the Palestinian side, it is a one man show. And Arafat was a very peculiar man to deal with.

Shlomo Ben-Ami's analysis of Arafat is very good. I don't know if you know it.

Cohen-Almagor:

I interviewed Shlomo Ben-Ami. Albright? Any thoughts about Albright?44

44. Madeleine Albright, secretary of state, 1997-2001,

https://www.britannica.com/biography/Madeleine-Albright.

Rabinovich:

I don't think she played a particular role in Camp David. She was there, but in no particular role.

Cohen-Almagor:

Do you know anything about the relationship between Barak and Albright?

Rabinovich:

Not great.

Cohen-Almagor:

Why?

Rabinovich:

I don't know. Before Barak was elected prime minister, I helped him in his foreign policy campaign. We went to see Albright, and she was determined not to irritate Bibi, because he had just signed the Wye agreement. 45

45. On 15-23 October 1998, Israel and the Palestinian Authority were invited by Clinton to take part in negotiations in Wye River, Maryland. After intensive negotiations that included Clinton's active participation, the Wye River Memorandum was signed. It restored old Israeli promises such as the opening of a Palestinian airport and a safe passage route between Gaza and the West Bank, as well as old Palestinian promises (publicly renouncing the PLO Charter's anti-Israel provisions, collecting unauthorized arms, and implementing antiterrorist actions). Its novelty was linking phased Israeli withdrawals to Palestinian actions and greatly enlarging the role of the United States as an active participant in both monitoring and judging the performance of the parties.

Cohen-Almagor:

Sorry, what year was that?

Rabinovich:

The Wye Plantation agreement, $13 \%$ of the West Bank.

Cohen-Almagor:

Yes, yes. When did you go to see her? 
This is an Accepted Manuscript of an article published by Taylor \& Francis in Israel Affairs on 20 Jun 2019, available online: http://www.tandfonline.com/ 10.1080/13537121.2019.1626092.

Rabinovich:

In '98. She was very cold to Barak and almost a hostile meeting. I mean, he was a candidate. That is the one time I saw them together.

Cohen-Almagor:

How do you explain that? Why?

Rabinovich:

Because she was told that 'You must not offend or irritate Bibi. Because we need Bibi to implement the Wye Plantation agreement.' We - the Americans.

Cohen-Almagor:

So, there was no personal thing.

Rabinovich:

No.

Cohen-Almagor:

Because Camp David came to a standstill when Clinton had to respect his commitment and went to Oceania.

Rabinovich:

Because Barak wanted to deal with Clinton directly, not with Albright.

Cohen-Almagor:

You were not consulted about Camp David, about the composition of the team. You were not invited.

Rabinovich:

I was invited to do the American media and I declined.

Cohen-Almagor:

What does that mean, 'to do the American media'?

Rabinovich:

To be the spokesperson.

Cohen-Almagor:

Outside of Camp David.

Rabinovich:

Outside.

Cohen-Almagor:

Do you think that the United States should put pressure on both sides to do a deal? 
This is an Accepted Manuscript of an article published by Taylor \& Francis in Israel Affairs on 20 Jun 2019, available online: http://www.tandfonline.com/ 10.1080/13537121.2019.1626092.

Rabinovich:

First of all, the United States needs to make up its mind that it is willing to invest in making a deal, sustained at a very high level. I don't see the Trump administration making that investment, given the overall set of issues and constraints, and given the character of the president. You know, I don't see Trump making the type of commitment and investment that presidents like Nixon, or Carter, or Clinton, or even George W. Bush made.

Cohen-Almagor:

You didn't mention Obama.

Rabinovich:

Obama, too, yes. Definitely during the first years of his presidency. Later he enabled Kerry to try his fortune but did not throw his full weigh behind him.

Cohen-Almagor:

Obama, too. Okay.

Rabinovich:

Yes, of course, yes. So, once the United States makes that decision and it decides to mobilize its resources and make the effort, it will also exert pressure. Not just exert pressure, but also exert pressure.

Cohen-Almagor:

Was it right for Clinton to try to exert pressure on Arafat at Camp David?

Rabinovich:

He should have. Clinton had no real leverage on either Assad or Arafat.

Cohen-Almagor:

So, you think that he tried to put pressure on Arafat?

Rabinovich:

Not effective pressure.

Cohen-Almagor:

Okay. So, pressuring both sides is something that you think the United States should do at some point.

Rabinovich:

Yes, when it decides that it wants to lead such a process.

Cohen-Almagor:

Okay. A few words about Taba.46

46. Between 21-27 January 2001, Israel and the Palestinian Authority held peace talks in Taba. These negotiations ultimately failed when Yasser Arafat did not accept a final bridging document 
This is an Accepted Manuscript of an article published by Taylor \& Francis in Israel Affairs on 20 Jun 2019, available online: http://www.tandfonline.com/ 10.1080/13537121.2019.1626092.

presented by President Clinton. Shortly thereafter, elections were held in Israel and PM Ehud Barak was voted out of office. See Pundak, "From Oslo to Taba."

What's the logic of convening a summit in Taba three weeks before the elections?

Rabinovich:

That was a very, very bad episode. Barak completely lost control. Members of his own cabinet conducted themselves on their own. They went much beyond the mandate. It really was a mess.

Cohen-Almagor:

Why did it happen? Why did he allow -

Rabinovich:

Because, at that point, it was clear that he had lost the government and was about to lose the elections. And, you know, people allow themselves things. It was a very bad episode.

Cohen-Almagor:

But it was his decision to go to Taba.

Rabinovich:

Because he was desperate. He wanted to salvage whatever could be salvaged. At that point, he was traveling downslope, trying to hang on to something.

Cohen-Almagor:

So, it was just bad decision-making, you think, on his part.

Rabinovich:

Yes.

Cohen-Almagor:

He was desperate.

Rabinovich:

Plus, you know, a government that is standing on one toe cannot negotiate seriously.

Cohen-Almagor:

Yes. So, if, supposedly, just theoretically, that there was a deal in Taba -

Rabinovich:

There was no deal in Taba.

Cohen-Almagor:

I know, but, if, supposedly, there would have been a deal in Taba, could it be, was it possible to salvage -

Rabinovich: 
This is an Accepted Manuscript of an article published by Taylor \& Francis in Israel Affairs on 20 Jun 2019, available online: http://www.tandfonline.com/ 10.1080/13537121.2019.1626092.

At that point, I'm not sure that Barak could have sold it to the public. There was a whole controversy about what was promised about right of return in Taba. By Beilin, I think. But, anyway, it came to nothing.

Cohen-Almagor:

So, you think it was a mistake.

Rabinovich:

It was a mistake.

Cohen-Almagor:

What do you think about Gaza 2005? Was it a mistake to evacuate Gaza?

Rabinovich:

Oh, no, definitely not. It could have been executed better. First of all, I think Sharon47

47. Ariel Sharon, prime minister of Israel, March 2001-April 2006.

should have brought in the Palestinian Authority. The Americans could have extracted from the Palestinians more for such a massive decision. And second, the Gaza process was never completed because Sharon fell ill and died. And thirdly, Bush's pressure to have the elections in Gaza was a bad mistake. Bush needed to justify the invasion of Iraq by showing that it contributed to democracy in the Middle East. The Palestinian elections were part of the proof. The result was that Hamas won the elections and we know the rest. So, you know, the decision was good, but it fitted into a bad context. Even though, if you ask all those who today criticize the decision, 'Do you want to go back to Gaza?', the answer is no, of course.

Cohen-Almagor:

Nobody wants Gaza. Do you think Hamas will ever change? Nowadays, there is a new leadership.

Rabinovich:

No. Hamas, is a fundamentalist Moslem movement. Fundamentalist remains fundamentalist.

Cohen-Almagor:

No moderation. Can't it be moderated?

Rabinovich:

Hamas can be a partner for a long term hudna but cannot be a partner to a final status agreement or any other agreement that recognizes Jewish sovereignty in Historic Palestine.

Cohen-Almagor:

Okay. Annapolis. What do you think about Annapolis?48

48. On 27 November 2007, US President Bush convened an international conference in Annapolis, MD to revive the Israeli-Palestinian peace process. Israeli Prime Minister Ehud Olmert and Palestinian Authority President Mahmud Abbas reached a joint understanding in which they agreed to launch continuous bilateral negotiations in an effort to conclude a peace treaty by the end of 
This is an Accepted Manuscript of an article published by Taylor \& Francis in Israel Affairs on 20 Jun 2019, available online: http://www.tandfonline.com/ 10.1080/13537121.2019.1626092.

2008 and to implement the American Road Map to a Permanent Two-State Solution to the IsraeliPalestinian Conflict.

What are the products? What are the outcomes of Annapolis?

Rabinovich:

Annapolis actually was a good conference, in the sense that it led to Olmert's plan. I guess you read Condoleezza Rice's memoirs.49

49. Condoleezza Rice, national security adviser, 2001-2005; secretary of state, 2005-2009. Author of No Higher Honor.

You know, she never expected something so far reaching, and she was also very much surprised by the fact that Abu Mazen didn't take it. So, Annapolis was successful. It led to what Olmert put on the table.

Cohen-Almagor:

So why didn't it work out in the end?

Rabinovich:

Because Olmert was on his hind legs, because Abu Mazen was not a real partner for a final status agreement. And the Bush administration did not fully exploit the opportunity.

Cohen-Almagor:

Are you familiar with the differences between Tzipi Livni and Ehud Olmert?

Rabinovich:

Not the fine points, no. Mostly personal. Not so much substance.

Cohen-Almagor:

No, no, there are substantive issues. Substance.

Rabinovich:

Yes, I know, but fundamentally they did not even like each other.

Cohen-Almagor:

So why did he make her chief negotiator? If he doesn't like and doesn't trust her?

Rabinovich:

Israeli politics.

Cohen-Almagor:

He had to?

Rabinovich:

He didn't have to, but, remember how Ehud Olmert became prime minister. He was not high on the party list. And Sharon, to keep him happy, he gave him the title of Memaleh Makom Rosh Hamemshala [Hebrew for Acting Prime Minister. Second in command]. When Sharon became ill, 
This is an Accepted Manuscript of an article published by Taylor \& Francis in Israel Affairs on 20 Jun 2019, available online: http://www.tandfonline.com/ 10.1080/13537121.2019.1626092.

Olmert became the successor. But Tzipi Livni was more important than him in the party. Olmert had to give her something. In Israeli politics, the prime minister appoints the foreign minister not as somebody who works for him, but normally because he has to give the position to his competitor.

Cohen-Almagor:

In my interview with Tzipi Livni she highlighted her role and lowered Olmert's role.

Rabinovich:

Did you speak to Dubi Weisglass?50

50. PM Sharon's bureau chief.

Cohen-Almagor:

Not, not yet.

Rabinovich:

You need to.

Cohen-Almagor:

Ok.

Rabinovich:

Yes, you should. Certainly on these issues.

Cohen-Almagor:

About settlements. Do you think that the clusters, the blocs, are they going to remain in Israel?

Rabinovich:

Sure. Yes.

Cohen-Almagor:

What about Ariel?

Rabinovich:

Also.

Cohen-Almagor:

That is a problem for the Palestinians.

Rabinovich:

It is a bigger problem for any Israeli government to dismantle Ariel. It is not feasible.

Cohen-Almagor:

It is not feasible.

Rabinovich:

No. 
This is an Accepted Manuscript of an article published by Taylor \& Francis in Israel Affairs on 20 Jun 2019, available online: http://www.tandfonline.com/ 10.1080/13537121.2019.1626092.

Cohen-Almagor:

And the security fence? Is it going to stay?

Rabinovich:

Maybe it will have to be adjusted, but not a bad idea, once it is there.

Cohen-Almagor:

You think it should remain. Jewish state. Is it really essential for the Palestinians to recognize Israel as a Jewish state?

Rabinovich:

There are issues like the Jewish state, and the Palestinian right of return, where there's a lot of room for flexibility. What needed is the right formulation. It can be sorted out.

Cohen-Almagor:

How?

Rabinovich:

I won't give you the precise formulation, but there's a way of overcoming the Jewish state obstacle. I don't think this is a substantive issue. If we come to a final deal, the Palestinians will have to accept Israel as the nation state of the Jewish people. You don't have to call it 'Jewish State'. You can call it by a different name. And Bibi also uses it, you know, as a stumbling block that he plants on the way to a deal.

Cohen-Almagor:

Are there any other issues that we need to speak about? Important issues we didn't cover?

Rabinovich:

No, I think we covered everything.

Cohen-Almagor:

Thank you very much.

Rabinovich:

Great! You're welcome.

\section{Conclusion}

Rabinovich notes five keys for successful peace negotiations between Israel and the PLO: (1) both sides need determination to close a deal. (2) Both sides should think that the rewarding outcomes would outweigh the 'pain', i.e. the costs they would need to pay. (3) both sides should feel that if they wait they would lose; thus, they better sign an agreement now. (4) supportive regional environment, and (5) effective American mediation.

Asked why Camp David 1978 was successful whereas Camp David 2000 ended in failure, Rabinovich explained that there is a difference between state-to-state negotiations and unequal negotiations that involve states and non-states. In 2000, Barak needed to address the Palestinian suspicions and sense of insecurity. He failed to do this. Not only that the Palestinians felt that they were the weaker 
This is an Accepted Manuscript of an article published by Taylor \& Francis in Israel Affairs on 20 Jun 2019, available online: http://www.tandfonline.com/ 10.1080/13537121.2019.1626092.

and vulnerable side, they soon realised that the United States was collaborating with the Israelis behind their backs. They did not trust Clinton and his team, and did not see the Americans as credible and unbiased moderator.

Furthermore, the Israeli-Palestinian conflict is not only about territory. The Palestinians demanded a sovereign state and an Israeli recognition of what the Palestinian perceived as their natural, historical rights. In addition, there was no sense of urgency among the Palestinians to resolve the conflict; Barak and Clinton lacked the required abilities to bring the negotiations to a successful conclusion. Finally, the Palestinians need the support of the Arab world. Being a weak side, they are acutely aware of the wider Arab interests and are, to a significant extent, dependent on the Arab world, in need of Arab backing. In 2000, this support was deficient.

Rabinovich does not think that, at present, there is any other country but the United States that can mediate between Israel and the Palestinians. Arab countries can play a vital role in supporting the Palestinians in the process as facilitators, but not as mediators. Small states, like Norway, may play a positive role, as it did in 1993.

Of all possible solutions, Rabinovich perceived the two state solution as the most viable. A new government, under different leadership and with different aspirations is needed to make this happen.

Rabinovich has dedicated much of his scholarly career to study Syria. Applying his five keys for successful negotiations to the Israeli-Syrian peace talks, it is evident why the talks ended in failure. The determination of both sides to come to an agreement was dubious. Balancing pain and reward, both were not convinced that the rewards outweighed pain. There was no sense of urgency for both to come to an agreement. Both thought that time was working for them, not against them. The regional environment was supportive, at least in part, and the United States was involved, trying to bridge the gaps between the two sides, but Secretary of State Christopher did not make prudent use of Rabin's deposit. Israel and Syria could not agree on the terms of the peace treaty. Both Israeli prime ministers, Rabin and Barak, did not wish to satisfy President Assad's territorial demands, whereas Assad was not prepared for full normalization with Israel.

Bibliography

Aderet, O. "Behind the Scenes of Anwar Sadat's Historic Visit to Jerusalem."

Haaretz, 27 November 2012. https://www.haaretz.com/.premium-when-sadatvisited-jerusalem1.5299445

Bercovitch, J., ed. Resolving International Conflicts: The Theory and Practice of Mediation. Boulder, CO: Lynne Rienner, 1996.

Carter, J. Keeping Faith: Memoirs of a President. NY: Bantam Books, 1982.

Clinton, W. J. My Life. NY: Knopf, 2010.

Cohen-Almagor, R. "The Oslo Peace Process: Interview with Joel Singer." Israel Affairs 24, no. 5 (2018): 733-766. doi:10.1080/13537121.2018.1505687.

Cohen-Almagor, R. "The Israel-PLO Peace Talks: Interview with Ambassador

Daniel Kurtzer." Israel Studies (2019). forthcoming. 
This is an Accepted Manuscript of an article published by Taylor \& Francis in Israel Affairs on 20 Jun 2019, available online: http://www.tandfonline.com/ 10.1080/13537121.2019.1626092.

Eizenstat, S. President Carter: The White House Years. NY: Thomas Dunne Books, 2018.

Eriksson, J. Small-State Mediation in International Conflicts: Diplomacy and Negotiation in IsraelPalestine. London: IB Tauris, 2015.

Friedman, T. L. "An Intriguing Signal from the Saudi Crown Prince." The New York Times, 17 February 2002.

Hirschfeld, Y. Track-Two Diplomacy toward an Israeli-Palestinian Solution 1978-2014. Washington: Woodrow Wilson Center Press and Johns Hopkins University Press, 2014.

Indyk, M. Innocent Abroad. NY: Simon and Schuster, 2009.

Kurtzer, D. C., S. B. Lasensky, W. B. Quandt, S. L. Spiegel, and S. Z. Telhami. The Peace Puzzle: America's Quest for Arab-Israeli Peace, 1989-2011. Ithaca, Washington: Cornell University Press, in Collaboration with the US Institute of Peace, 2013.

Miller, D. A. The Much Too Promised Land: America's Elusive Search for Arablsraeli Peace. NY: Bantam, 2008.

Miller, D. A. "How Not to Host a Summit." Foreign Policy, 10 July 2012.

Olmert, E. In First Person. Tel Aviv: Yedioth Ahronoth, 2018. (Hebrew).

Pressman, J. "Visions in Collision: What Happened at Camp David and Taba?" International Security 28, no. 2 (2003): 5-43. doi:10.1162/016228803322761955.

Pruitt, D. "Ripeness Theory and the Oslo Talks." International Negotiation 2, no. 2 (1997): 237-250. doi:10.1163/15718069720847960.

Pundak, R. “From Oslo to Taba: What Went Wrong?" Survival 43 (2001): 31-45. doi:10.1080/00396330112331343035.

Pundak, R. Secret Channel. Tel Aviv: Aliyat Hagag, 2013. (Hebrew).

Quandt, W. Peace Process: American Diplomacy and the Arab-Israeli Conflict since 1967. Berkeley, CA: University of California Press, 2005.

Rabinovich, I. Syria under the Ba'th: 1963-1966: Army-Party Symbiosis. NJ: Transaction, 1972.

Rabinovich, I. The War for Lebanon, 1970-1985. Ithaca: Cornell University Press, 1985.

Rabinovich, I. The Road Not Taken: Early Arab-Israeli Negotiations. New York: Oxford University Press, 1991.

Rabinovich, I. The Brink of Peace: The Israeli-Syrian Negotiations. Princeton, NJ: Princeton University Press, 2001.

Rabinovich, I. The Lingering Conflict: Israel, the Arabs, and the Middle East, 1948-2011. Washington, DC: Brookings Institution Press, 2011.

Rabinovich, I. The View from Damascus: State, Political Community and Foreign Relations in Modern and Contemporary Syria. Herts: Vallentine Mitchell, 2011.

Rabinovich, I. Receding Horizon. Modi'in: Dvir, 2012. (Hebrew).

Rabinovich, I. Yitzhak Rabin: Soldier, Leader, Statesman. New Haven: Yale University Press, 2018. 
This is an Accepted Manuscript of an article published by Taylor \& Francis in Israel Affairs on 20 Jun 2019, available online: http://www.tandfonline.com/ 10.1080/13537121.2019.1626092.

Rice, C. No Higher Honor. New York: Crown, 2011.

Ross, D. The Missing Peace. New York: Farrar, Straus and Giroux, 2004.

Sadat, A. E. In Search of Identity. NY: Harpercollins, 1978.

Sicherman, H. Palestinian Autonomy, Self-Government and Peace. Boulder, CO: Westview, 1993.

“Text: Arab Peace Plan of 2002." BBC. http://news.bbc.co.uk/1/hi/world/middle_east/1844214.stm

Thrall, N. "Israel \& the US: The Delusions of Our Diplomacy." NY Review of Books, 9 October 2014

Waage, H. H. Peacemaking Is a Risky Business: Norway's Role in the Peace Process in the Middle East, 1993-96. Oslo: International Peace Research Institute PRIO, 2004.

Weizman, E. The Battle for Peace. NY: Bantam, 1981.

Zartman, I. W. Ripe for Resolution. New York and Oxford: Oxford University Press, 1989.

Zion, S. "Untold Story of the Mideast Talks." NY Times, 21 January 1979.

https://www.nytimes.com/1979/01/21/archives/untold-story-of-the-mideast-talksmideast.html 